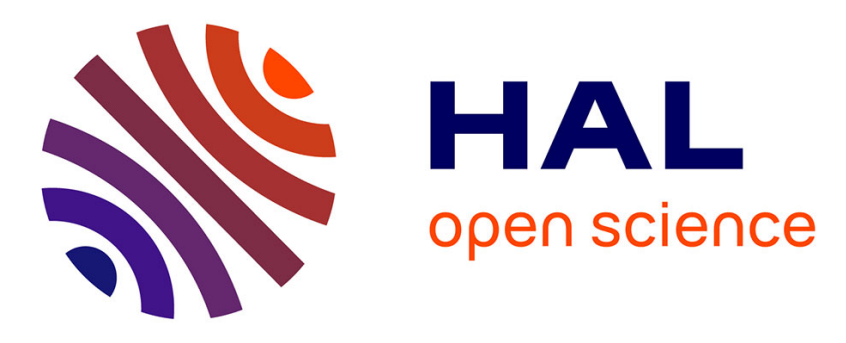

\title{
Weak competitive ability may explain decline of Taxus baccata
}

\author{
Iszkulo, Didukh, Marian Giertych, Anna Jasińska, Sobierajska, Szmyt
}

\section{To cite this version:}

Iszkulo, Didukh, Marian Giertych, Anna Jasińska, Sobierajska, et al.. Weak competitive ability may explain decline of Taxus baccata. Annals of Forest Science, 2012, 69 (6), pp.705-712. 10.1007/s13595012-0193-4 . hal-00930843

\section{HAL Id: hal-00930843 https://hal.science/hal-00930843}

Submitted on 1 Jan 2012

HAL is a multi-disciplinary open access archive for the deposit and dissemination of scientific research documents, whether they are published or not. The documents may come from teaching and research institutions in France or abroad, or from public or private research centers.
L'archive ouverte pluridisciplinaire HAL, est destinée au dépôt et à la diffusion de documents scientifiques de niveau recherche, publiés ou non, émanant des établissements d'enseignement et de recherche français ou étrangers, des laboratoires publics ou privés. 


\title{
Weak competitive ability may explain decline of Taxus baccata
}

\author{
Grzegorz Iszkuło • Yakiv Didukh • Marian J. Giertych • \\ Anna K. Jasińska $\cdot$ Karolina Sobierajska $\cdot$ Janusz Szmyt
}

Received: 6 July 2011 / Accepted: 6 February 2012 / Published online: 29 February 2012

(C) The Author(s) 2012. This article is published with open access at Springerlink.com

\begin{abstract}
- Context Taxus woodlands suffer from a lack of natural regeneration across its whole distribution range.

- Aims In Knyazhdvir Reserve in Ukraine Taxus baccata primarily competes with Abies alba. It has been assumed that in the conditions of deep shade, yews have a greater competitive advantage than firs.

- Methods To verify this hypothesis, a plot with both species growing under the canopy was established. Wood samples were taken from 20 trees of $T$. baccata and 20 trees of A. alba. - Results There were no differences in the mean tree-ring width, height and age between both species. Due to a lack of
\end{abstract}

\section{Handling Editor: Douglass Jacobs}

Contribution of the co-authors G. Iszkuło: writing the manuscript, running the experiment, analysing data, designing the experiment Y. Didukh: supervising

M. Giertych: writing the manuscript, running the experiment, analysing data

A. Jasińska: running the experiment

K. Sobierajska: running the experiment

J. Szmyt: writing the manuscript, analysing data

G. Iszkuło • M. J. Giertych

Institute of Dendrology, Polish Academy of Sciences,

Parkowa 5,

62-035 Kórnik, Poland

G. Iszkuło $(\bowtie) \cdot$ M. J. Giertych

Faculty of Biological Sciences Prof. Z. Szafrana 1,

University of Zielona Góra,

65-516 Zielona Góra, Poland

e-mail: iszkulo@man.poznan.pl

\section{Y. Didukh}

National Academy of Sciences of Ukraine, M.G. Kholodny

Institute of Botany,

2, Tereschenkivska str.,

01601 Kyiv, Ukraine

e-mail: didukh@botan.kiev.ua spatial separation of both species, yews and firs inhabited the same area in the analysed plot. Fir seedlings (up to $0.5 \mathrm{~m}$ ) were recorded to grow under yew saplings (above $0.5 \mathrm{~m}$ ), but the inverse situation of yew seedlings growing under fir saplings was not seen.

- Conclusion Seedling distribution, tree-ring growth rate, possibility of growth of fir seedlings under yew saplings and greater potential growth suggested that fir was predisposed to having the competitive edge over yew. Our results may confirm the hypothesis that $T$. baccata has a restricted distribution because of weak competitive abilities and can exist only in habitats where faster growing species are

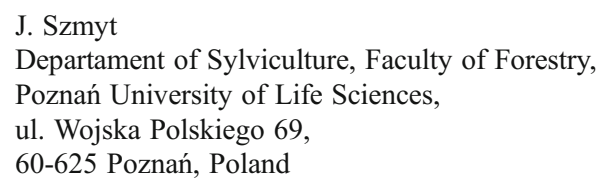

A. K. Jasińska • K. Sobierajska

Institute of Dendrology, Polish Academy of Sciences, Parkowa 5,

62-035 Kórnik, Poland 
absent. The results call into question the prevailing opinion that human influences are the principal cause for the decline of T. baccata.

Keywords European yew · Silver fir · Growth rate . Competition

\section{Introduction}

Taxus baccata is a rare species throughout its entire natural range and is often categorized as nationally threatened in countries where it occurs (Thomas and Polwart 2003; Schirone et al. 2010) and the woodlands with Taxus have received priority habitat status under Annex I of the EU Habitats Directive. In most localities in Europe, Taxus populations have declined due to the lack of natural regeneration. Most often, all seedlings die in the first or second year, although initially their number is high (Thomas and Polwart 2003). The main reasons for seedling mortality are grazing by deer (Perrin et al. 2006), excessive shading (Iszkuło and Boratyński 2006), interaction of low temperature and light availability (Iszkuło 2010) and drought in the Mediterranean region (Sanz et al. 2009). Dioecy may also adversely affect the mortality of yew (Iszkuło et al. 2009; Cedro and Iszkuło 2011). The passive protection of European yew populations and the lack of thinning in the natural reserves have resulted in excessive canopy density and, consequently, lack of reproduction success (Dhar et al. 2008).

According to the classifications, yews and firs are considered shade-tolerant species (Ellenberg et al. 1991; Brzeziecki and Kienast 1994). However, the yew is thought of as the most shade-tolerant woody species in central Europe (Thomas and Polwart 2003).

To date, the growth rate of natural regeneration of yews and firs occurring at the same site has not been compared. The simultaneous occurrence of firs and yews in Knyazhdvir Reserve in Ukraine creates a unique opportunity to better understand the biology of both species, which will help to actively protect threatened species T. baccata (Iszkuło et al. 2011). There was no sign of grazing on the seedlings in the reserve, which confirms earlier observations that the place is free from intense animal disturbance (Iszkuło et al. 2005). This allows us to eliminate the factor of grazing from analysis.

Different authors have often noticed grouped distribution of young trees in forests. It is often the result of larger or smaller natural gaps in the canopy of the stand (Leemans 1991). Geostatistical analysis in the Central Apennines found that yew occurred in patches and high density of mature yews suppressed regeneration (Piovesan et al. 2009). The presence of gaps leads to a change in ecological conditions under the canopy. One of the most important ecological factors, especially important for natural regeneration, is light conditions on the forest floor (Szwagrzyk et al. 2001). The analysis of the horizontal spatial organisation of the forest allows us to study the relationships between younger and older trees (Leemans 1991; Szwagrzyk et al. 2001; Szymura et al. 2007). Spatial relationships between different naturally regenerating species in a mixed forest are particularly interesting because such knowledge could help us to explain the natural species change in the mixed forest. It can also lead to some interesting conclusions about the possibility of species coexistence or their mutual competition (Fajardo and Gonzales 2009).

The main hypothesis of the present study is that yews grow better under the shade of the forest canopy than firs. The secondary hypotheses are as follows: (1) the growth rate in shade and high competition conditions is higher for yews than for firs; (2) yew and fir individuals are clumped, suggesting that both species occupy different habitats and (3) individuals of both species described as seedlings and saplings are distributed independently from each other which means that there are not mechanisms responsible for attraction or repulsion between them.

\section{Material and methods}

\subsection{Field study}

The study was conducted in the Knyazhdvir Nature Reserve

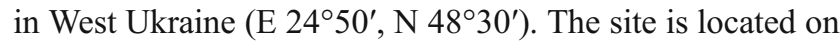
the north-eastern Carpathian foothills, on the north-facing slopes above Prut River, at an elevation of 320 to $460 \mathrm{~m}$ above sea level. The slopes are composed of Neogene sandstones covered with Pleistocene deposits, mostly alisols. It is crossed by the Prut River, with exposures of several waterbearing horizons. The steepness of the slopes coupled with a permanent water logging causes landslides. Frequently leached and permanently humid cambiosols predominate within the nature reserve. Nowadays, T. baccata occurs mainly in the sub-canopy of the stand.

Data were collected from a $25 \times 25$-m plot. The plot location was chosen at a site presenting a forest with high natural regeneration of Abies alba and T. baccata. Characteristics of studied species are described in Table 1. Height, diameter and coordinates for each individual tree were recorded. Core samples from 40 individuals (20 from yew and 20 from fir) were collected with a Pressler borer at breast height.

The two core samples from one tree were scanned at 1,200 dpi. The tree ring-widths were measured using a WinDendro $^{\mathrm{TM}}$ (Ver. 2008d) software to the nearest $0.001 \mathrm{~mm}$. The average tree ring-widths from two cores 
Table 1 Ecological characteristics of Taxus baccata and Abies alba

\begin{tabular}{|c|c|c|}
\hline Trait & Taxus baccata & Abies alba \\
\hline Division & Gymnosperm & Gymnosperm \\
\hline Seed dispersal & $\begin{array}{l}\text { Bird dispersed } \\
\text { (zoochory) }\end{array}$ & $\begin{array}{r}\text { Wind dispersed } \\
\text { (anemochory) }\end{array}$ \\
\hline Tree layer & Understory & Canopy \\
\hline Light requirement & Shade tolerant & Shade tolerant \\
\hline Mating system & Dioecious & Monoecious \\
\hline Potential growth & Low tree & High tree \\
\hline Potential age & Long-lived & Long-lived \\
\hline
\end{tabular}

were the base for further analysis. The signal homogeneity was subsequently verified using the COFECHA software (Holmes 1994).

Light intensity of the environment was determined at 20 points in the study area. The photosynthetic photon flux density (PPFD) was measured using a Line Quantum Sensor (Apogee Inc.), which is $1 \mathrm{~m}$ long and contains 20 photometers $5 \mathrm{~cm}$ apart. The PPFD measurements were taken from the top of dominant $T$. baccata and A. alba individuals on a cloudy day, according to the methods used by Iszkuło and Boratyński (2006). PPFD was also recorded in an open area with a Light Sensor (Apogee Inc.). Relative PPFD values were calculated as the ratio of average PPFD in the subplot to the PPFD in the open area.

The JMP software (SAS Institute) was used for the $t$ test analysis after finding the normality of the distribution of the mean age, tree-ring width and average height of $T$. baccata and $A$. alba.

\subsection{Spatial structure}

Ripley's function was used to perform a spatial analysis of the distribution of yew regeneration in the Knyazhdvir Nature Reserve. This method is based on the distances between all individuals in a given area (Haase 1995; Salas et al. 2006). This procedure was performed for each tree at different distances "d" (up to $d_{\text {max }}$ ). The graph of the $K(d)$ function for the observed values was then compared to the graph with the theoretical model, which assumed the null hypothesis (Poisson model). $W_{\mathrm{ij}}$ correlation coefficients were used to solve the edge effect problems (Haase 1995). The advantage of this method is the possibility of determining the type of individual distribution depending on the spatial scale. The analysis was done using the SPPA Software v2.0.3.

\subsubsection{Univariate analysis}

The univariate analysis was performed for all living individuals, irrespective of their species and size, and separately

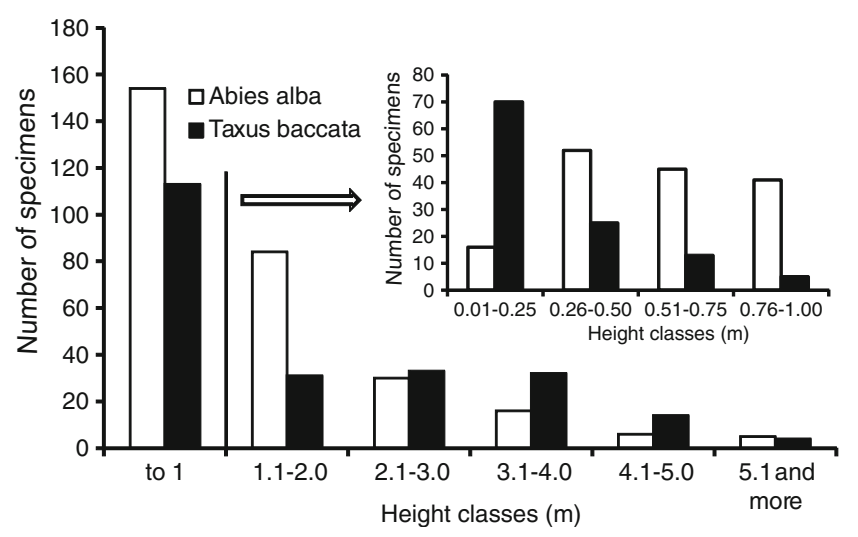

Fig. 1 The number of individuals of yew (white bars) and fir (black bars) in $1 \mathrm{~m}$ height class. Class to $1 \mathrm{~m}$ is divided to $0.25 \mathrm{~m}$ additional height classes

for yew and fir regeneration. Ripley's $K^{\prime}(d)$ function takes the form: $K^{\prime}(d)=\frac{A}{n^{2}} \sum_{i=1}^{n} \sum_{j=1}^{n} \frac{1}{w_{i j}} I_{t}\left(u_{i j}\right)$, where: $A=$ surface $\left(\mathrm{m}^{2}\right), n=$ number of trees, $u_{\mathrm{ij}}=$ distance $(d)$ between "i" tree and " $\mathrm{j}$ " tree, $I_{i j}=1$ for $u_{i j} \leq d, I_{i j}=0$ otherwise, $w_{i j}=$ marginal effect of the correction factor (Haase 1995; Salas et al. 2006). Besag (1977) proposed transformation of $K^{\prime}(d)$ into $L^{\prime}(d): L^{\prime}(d)=\sqrt{K^{\prime}(d) / \pi}-d . L^{\prime}(d)$ stabilises the variance of the $K^{\prime}(d)$ estimator and is a linear function that facilitates the interpretation of the results. The statistical significance of the observed deviations of $L^{\prime}(d)$ from the theoretical model (CSR) was determined by the Monte Carlo method (Haase 1995). Ninety-nine simulations were undertaken to determine a $95 \%$ confidence interval. In the case of a random distribution of individuals, $L^{\prime}(d)$ was equal to zero. $L^{\prime}$ (d) $>0$ indicated that individuals were aggregated, while $L^{\prime}$ $(d)<0$ showed that the individuals were regularly spaced.

\subsubsection{Bivariate analysis}

Bivariate analysis was performed to investigate the spatial relationships between: (1) regeneration of yews and firs, (2) seedlings and saplings of yew, (3) seedlings and saplings of fir, (4) saplings of yew $(H>50 \mathrm{~cm})$ and seedlings of fir $(H \leq$

Table 2 Characteristics of the analysed trees

\begin{tabular}{|c|c|c|c|c|}
\hline Species & $n$ & Age (SE) & $\begin{array}{l}\text { Tree-ring } \\
\text { width (SE) } \\
(\mathrm{mm})\end{array}$ & $\begin{array}{l}\text { Average height } \\
\text { increment } \\
\left(\mathrm{mm} \mathrm{year}^{-1}\right)\end{array}$ \\
\hline $\begin{array}{l}\text { Abies } \\
\text { alba }\end{array}$ & 20 & $37.7(3.40)$ & $0.670(0.026)$ & $125.6(8.73)$ \\
\hline $\begin{array}{l}\text { Taxus } \\
\text { baccata }\end{array}$ & 20 & $39.3(2.42)$ & $0.696(0.036)$ & $136.2(11.1)$ \\
\hline
\end{tabular}


$50 \mathrm{~cm})$ and $(5)$ saplings of fir $(H>50 \mathrm{~cm})$ and seedlings of yew $(H \leq 50 \mathrm{~cm})$.

The estimator of Ripley's function for this type of analysis has the form (Haase 1995): $K_{12}^{\prime}(d)=\frac{n_{2} K_{12}^{\prime}(d)+n_{1} K_{21}^{\prime}(d)}{n_{1}+n_{2}}$ and the transformation into $L_{12}^{\prime}(d)$ takes the form: $L_{12}^{\prime}$ $(d)=\sqrt{K_{12}^{\prime}(d) / \pi}-d$. When the value of $L_{12}^{\prime}(d)=0$, it can be stated that the individuals from the different populations occurred independently from each other. When $L_{12}^{\prime}(d)>0$, it indicates that the individuals showed a "mutual attraction" and when $L_{12}^{\prime}(d)<0$, it indicates that the individuals demonstrated "mutual repulsion" (segregation). The significance of deviations was determined by Monte Carlo using 99 simulations ( $95 \%$ confidence intervals). The null hypothesis was the hypothesis of independence of the distribution of both species and size classes (Fajardo et al. 2006).

\section{Results}

\subsection{Characteristic of A. alba and T. baccata populations}

The crown layer of the studied plot consisted of nine individuals of Fagus sylvatica with a height ranging between 17.0 and $38.0 \mathrm{~m}$, two specimens of $A$. alba with heights of 24.0 and $25.5 \mathrm{~m}$ and an individual of Acer platanoides $27.5 \mathrm{~m}$ tall.

The second layer of sapling was dominated primarily by A. alba (295 individuals) and T. baccata (227 individuals). Nine individuals of $F$. sylvatica, seven of $A$. platanoides and four individuals of Corylus avellana were also found.

Light measurement (RPPFD) above the top of the sapling layer showed that the range of light was mainly between $1.8 \%$ and $3.2 \%$ with an average of $2.5 \%$ PPFD.

The Taxus was dominant in the lowest height class of $25.0 \mathrm{~cm}$ and in the classes of heights between 2.1 and $5.0 \mathrm{~m}$. The other height classes were dominated by silver fir individuals (Fig. 1).

Fig. 2 Tree-ring width of Taxus baccata (solid line) and Abies alba (dotted line) populations over the years
The mean age, tree-ring width and average height increment (Table 2) did not differ significantly between yews and firs ( $t$ test).

The radial growth of $A$. alba and T. baccata at the beginning of their growth was very similar from the 1960s to the early 1970s. From then, yews showed greater radial growth than the firs until 1983. It was from that moment that a decrease in treering growth was observed for both species, but the growth rate was lower in the yews than in the firs (Fig. 2).

\subsection{Spatial analysis}

In the case of univariate analysis of yews (Fig. 3a) and firs (Fig. 3b), Ripley's function pointed out that the cluster size for both species was almost the same (about $7.5 \mathrm{~m}$ ). However, the two species differed in the intensity of the cluster. In the case of yews, the maximum value of the Ripley's function was observed at a distance of approximately $0.2 \mathrm{~m}$, while it was about $6.8 \mathrm{~m}$ for fir trees. From the two graphs it can also be seen that the clumps of regeneration were randomly distributed in the plot (Fig. 3)

Bivariate Ripley's function for yew and fir seedlings $(H \leq$ $50 \mathrm{~cm}$ ) did not deviate from the null model (Poisson model) in almost all the distance classes, which indicated the mutual independence of both species (Fig. 4a). The deviations from the theoretical model occured either in the direction towards groups of individuals (up to about $5 \mathrm{~m}$ ) or in the direction of their spatial separation (distance $>5 \mathrm{~m}$ ). In the case of saplings of both species, statistically significant deviations from the theoretical model were found at the scale 1-9 m and they tend towards mutual attraction of fir and yew saplings (Fig. 4b).

Individuals classified as seedlings $(H \leq 50 \mathrm{~cm})$ and saplings $(H>50 \mathrm{~cm})$ in the case of yew were characterized by the mutual segregation of their spatial distribution (Fig. 5a) revealing the presence of the mechanism making the spatial separation of seedlings and saplings of yew. In the case of fir trees, the hypothesis of mutual independence of distribution

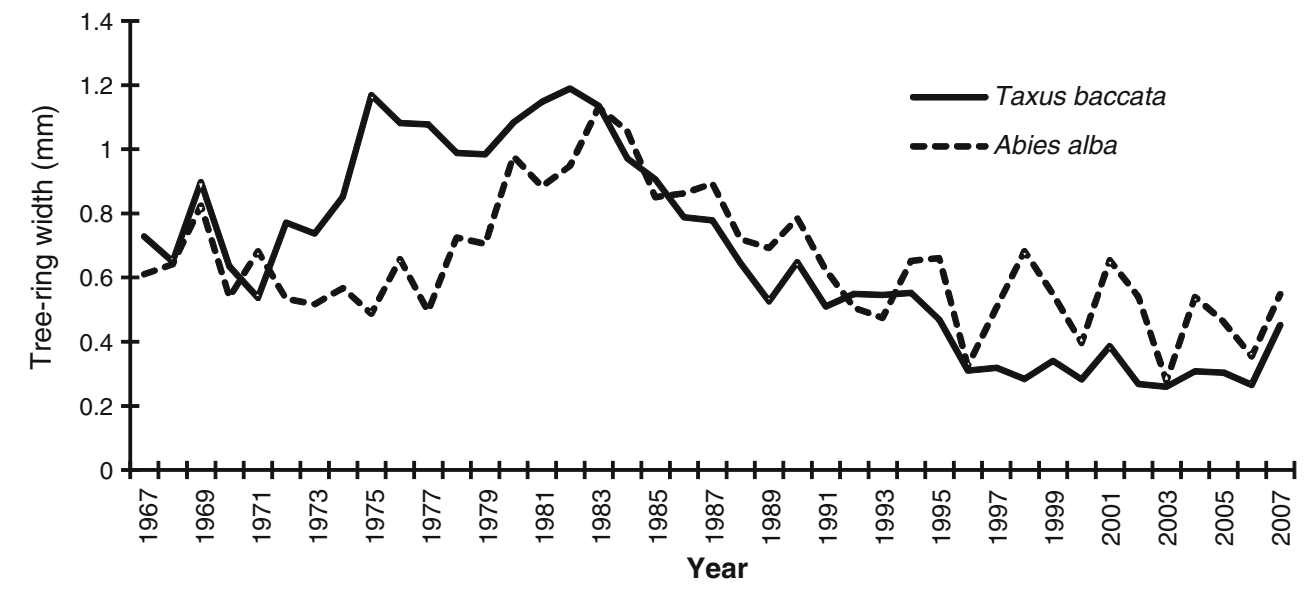


Fig. 3 Ripley's $L^{\prime}(d)$ function for yew (a) and fir (b) representing all living individuals. Dashed lines upper and lower confidential bounds $(\alpha=0.05)$; solid line function for empirical data
(A)

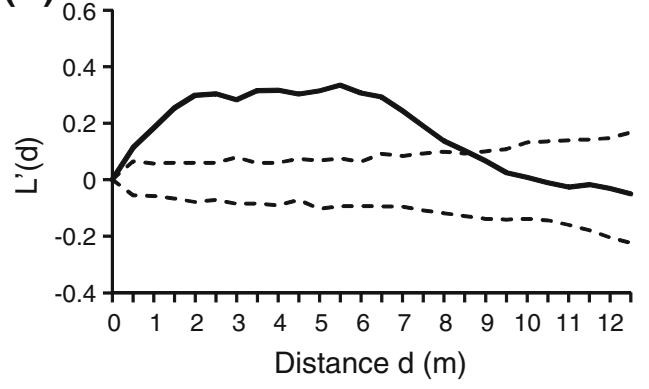

(B)

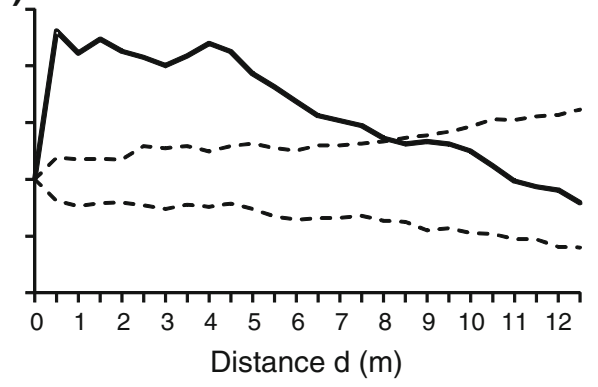

of seedlings and saplings was not rejected. At the whole spatial scale analysed, the deviations from the theoretical model were not statistically significant (Fig. 5b).

The location of yew saplings and fir seedlings showed a very clear mutual attraction between the individuals of both species (Fig. 6a). This positive correlation was observed in the entire investigated range of distances. A different situation occurred when yew seedlings and fir saplings were taken into consideration (Fig. 6b). In this case the graph of $L^{\prime}(d)$ function showed a clear inclination toward a segregation of both species, but these deviations were statistically significant only at distances larger than $3 \mathrm{~m}$ (Fig. 6b).

\section{Discussion}

The low light intensity in the analysed plot (an average of $2.5 \%$ PPFD) was the minimum light value necessary for yews, but too low for silver fir. According to previous studies, yew seedlings need at least 2-3\% (Iszkuło and Boratyński 2006) and fir seedlings $8-12 \%$ of PPFD for successful regeneration (Filipiak et al. 2005; Szymura et al. 2007). The values of light intensity in the analysed population should favour the colonisation and growth rate of yews. However, the seedling distribution, tree-ring growth rate, possibility of fir seedling growth under yew saplings and larger potential growth than Taxus point to the fir tree as the species predisposed to having a competitive edge over the yew.
Both species are classified similarly in terms of light requirements (Ellenberg et al. 1991; Brzeziecki and Kienast 1994). However, yew (as opposed to the fir) is a typical species of the second forest layer and is widely regarded as a species with lower light requirements (Thomas and Polwart 2003). The value of the average tree-ring width of yew over the studied area $(0.696 \mathrm{~mm})$ was comparable with other populations of this species (from 0.29 to $1.44 \mathrm{~mm}$; Cedro and Iszkuło 2011). However, the potential tree-ring width for the fir tree is much higher than that recorded in the studied area $(0.670 \mathrm{~mm})$. The average increment for fir trees was often greater than $2 \mathrm{~mm}$ (Carrer et al. 2010; Diaci and Firm 2011; Iszkuło et al. 2011).

More yews than firs occur in the lowest size classes (the youngest), the abundance of seeds ensures an adequate number of yew seeds for regeneration (Iszkuło and Boratyński 2005). Large number of small seedlings is a typical situation observed in many populations of yew, where there is a large number of seedlings that disappears after a few years (Thomas and Polwart 2003; Iszkuło and Boratyński 2006). The reason for fewer fir seedlings in comparison to yews is probably due to less frequent abundant seed production years, which occurs every 3 to 4 years for fir (Suszka 1983), and every 1 to 2 years for yew (Thomas and Polwart 2003). A larger number of yew specimens were also observed in height classes above $2 \mathrm{~m}$. This can be caused by favourable growing conditions for this species as observed in the growth rate that occurred in the 1970s (Fig. 2).

A large number of the younger fir generation $(0.25$ to $2 \mathrm{~m})$ together with the dominance of fir growth over recent years
Fig. 4 Bivariate Ripley's $L^{\prime}(d)$ function for yew and fir seedlings (a) and saplings (b). Dashed lines upper and lower confidential bounds $(\alpha=0.05)$; solid line function for empirical data
(A)

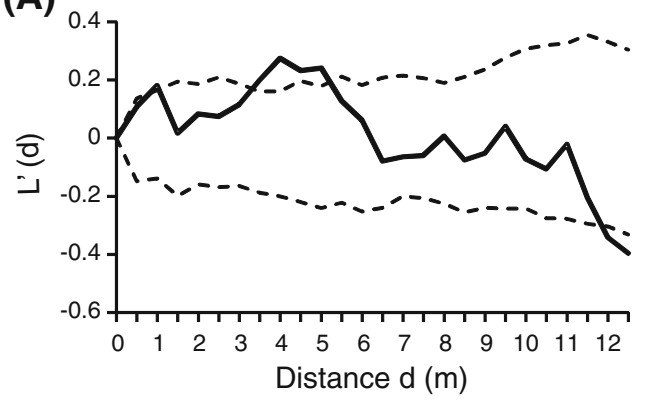

(B)

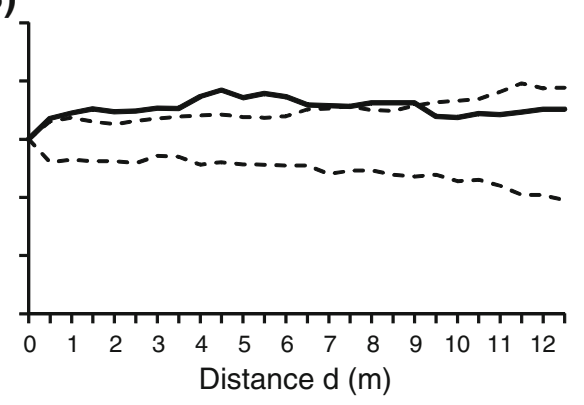


Fig. 5 Bivariate Ripley's $L^{\prime}(d)$ function for yew (a) and fir (b) seedlings and saplings. Dashed lines upper and lower confidential bounds $(\alpha=0.05)$; solid line function for empirical data
(A)

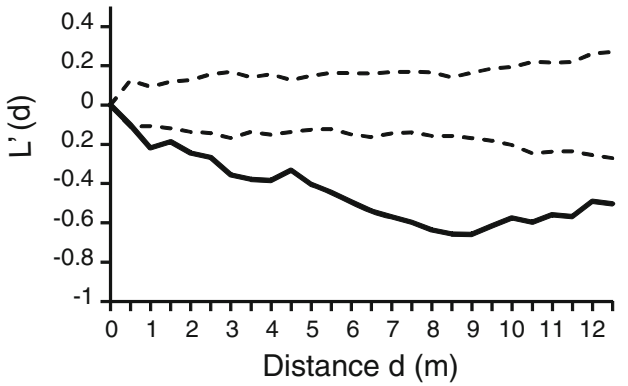

(B)

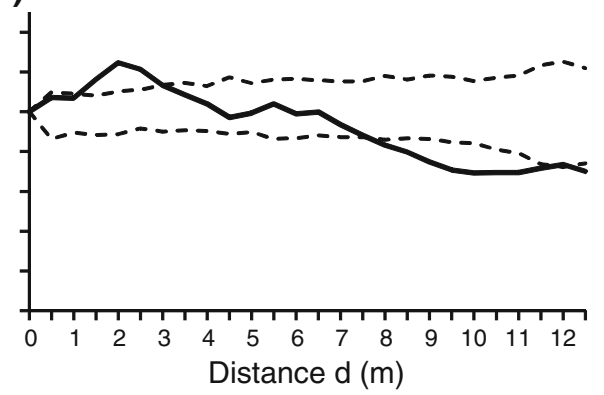

indicates that the fir is a species with a greater competitive advantage than the yew. The chance for survival would be growth of both species in different ecological habitats. Spatial analysis did not indicate a segregation of these species in the study area. Interspecific competition was not analysed in this study. It is well-known that T. baccata can grow for a very long time in unfavourable light conditions (Thomas and Polwart 2003). It appears that in conditions of strong competition with fir, only the possibility of greater survival under conditions of strong shadow may give a chance for yews to survive. Differences in the spatial pattern of yews and firs resulted primarily from the way of seed dispersion. In the case of T. baccata, it is a zoochory, with animals and especially birds (Lu et al. 2008), while dispersal of A. alba seeds is by wind (anemochory). The result is that the highest clumping of yew tree occurs within $0.2 \mathrm{~m}$, which corresponds to the area of deposition of birds excrements. In the case of fir, maximum deviation from the random distribution model was much larger and was at a distance of approximately $4 \mathrm{~m}$.

The positive correlation between the occurrence of yew saplings and fir seedlings indicates that the conditions under yew saplings are favourable for fir seedlings. Negative allelopathic effects of yew and fir on the germination and growth of seedlings have been demonstrated in several studies (Del Moral and Cates 1971; Pelliser and Souto 1999; Thomas and Polwart 2003; Piovesan et al. 2009). However, the allelopathic effects of yew saplings were not evident with the coexistence of fir seedlings. This relationship was not found in the case of fir saplings and yew seedlings. It appears that the fir tree, compared to the yew, is a more effective inhibitor of germination and/or seedling growth. The consequence of this state in terms of coexistence of these two species may be the ousting of yew by fir. It seems that even after an opening in the canopy, a fir tree is more likely to experience faster growth in comparison with yew. Similarly, strong competitive abilities of $A$. alba were found in the western Alps. Silver fir was more resistant to low growth and had lower mortality in comparison with Picea abies (Vieilledent et al. 2010). However, the decline of Abies alba in natural ecosystems is more often observed (Thomas et al. 2002; Camarero et al. 2011; Ficko et al. 2011; Klopcic and Boncina 2011).

These results may confirm an opinion that $T$. baccata has restricted distribution because of weak competitive abilities (Thomas and Polwart 2003) and can exist only in habitats where fast-growing species are absent (Scheeder 1994). Similar conclusions results from palaeobotanical studies. The optimum occurrence of yew in interglacials was at the time of the absence of other shade-tolerant species (Averdieck 1971; Kozakova et al. 2011) and remained only on relict stands (Krupiński et al. 2004). This view calls into question prevailing opinion of human dominant role in decline of $T$. baccata populations (Lyubenova and Nedelchev 2001; Thomas and Polwart 2003).

\section{Conclusions}

T. baccata often occurs together with A. alba in central Europe. These two species are shade tolerant. However, due to its growth in the second layer, the yew tree is considered to be more tolerant to shade than fir. Since T. baccata is a rare
Fig. 6 Bivariate Ripley's $L^{\prime}(d)$ function for yew saplings and fir seedlings (a) and fir upgrowth and yew seedlings (b). Dashed lines upper and lower confidential bound $(\alpha=0.05)$; solid line function for empirical data
(A)

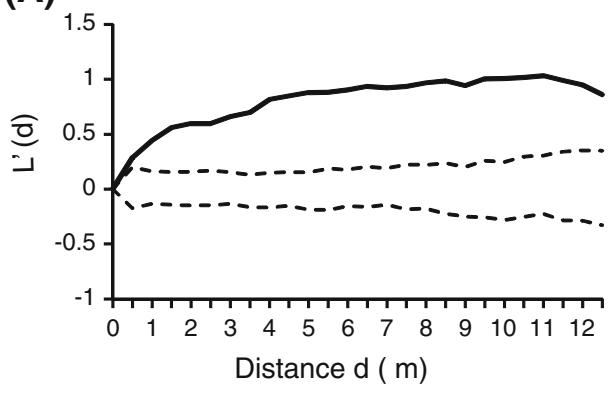

(B)

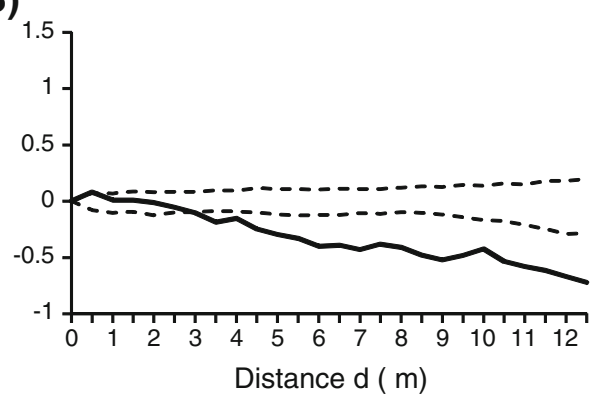


and often threatened species, the assumed greater shadetolerance would give it a competitive advantage over the silver fir. However, during the study, it was found that the fir tree in deep shade conditions showed a greater growth rate than the yew. The young fir seedlings could grow under yew saplings, while yew seedlings did not grow under fir saplings. Higher potential growth of fir compared to yew predisposes this species to have the competitive edge over yew.

Acknowledgements We thank Dr. Dmytro Iakushenko for the help in our field work. We are grateful to Tom Christian for the language correction of the final version of the manuscript. We would like to thank the anonymous referees. Their comments strongly improved the manuscript.

Funding This study was supported by the Institute of Dendrology, Polish Academy of Sciences, Kórnik, Poland.

Open Access This article is distributed under the terms of the Creative Commons Attribution License which permits any use, distribution, and reproduction in any medium, provided the original author(s) and the source are credited.

\section{References}

Averdieck FR (1971) Zur postglacialen Geschichte der Eibe (Taxus baccata L.). Nordwestdeutschland. Flora 160:28-42

Besag J (1977) Contribution to the discussion of Dr Ripley's paper. J R Stat Soc B 39:193-195

Brzeziecki B, Kienast F (1994) Classifying the life-history strategies of trees on the basis of the Grimian model. For Ecol Manag 69:167187

Camarero JJ, Bigler C, Linares JC, Pelegrin E (2011) Synergistic effects of past historical logging and drought on the decline of Pyrenean silver fir forests. For Ecol Manag 262:759-769

Carrer M, Nola P, Motta R, Urbinati C (2010) Contrasting tree-ring growth to climate responses of Abies alba toward the southern limit of its distribution area. Oikos 119:1515-1525

Cedro A, Iszkuło G (2011) Do females differ from males of European yew (Taxus baccata L.) in dendrochronological analysis? TreeRing Res 67:3-11

Del Moral R, Cates RG (1971) Allelopathic potential of the dominant vegetation of western Washington. Ecology 52:1030-1037

Dhar A, Ruprecht H, Vacik H (2008) Population viability risk management (PVRM) for in situ management of endangered tree species-a case study on a Taxus baccata L. population. For Ecol Manag 255:2835-2845

Diaci J, Firm D (2011) Long-term dynamics of a mixed conifer stand in Slovenia managed with a farmer selection system. For Ecol Manag 262:931-939

Ellenberg H, Weber HE, Düll R, Wirth V, Werner W, Paulissen D (1991) Zeigerwerte der Gefäßpflanzen Mitteleuropas. Scr Geobotanica 18:1-122

Fajardo A, Gonzales ME (2009) Replacement patterns and species coexistence in an Andean Araucaria-Nothofagus forest. J Veg Sci 20:1176-1190

Fajardo A, Goodburn JM, Graham J (2006) Spatial patterns of regeneration in managed uneven-eged ponderosa pine/Douglas-fir forests of Western Montana, USA. For Ecol Manag 223:255266
Ficko A, Poljanec A, Boncina A (2011) Do changes in spatial distribution, structure and abundance of silver fir (Abies alba Mill.) indicate its decline? For Ecol Manag 261:844-854

Filipiak M, Iszkuło G, Korybo J (2005) Relation between photosynthetic photon flux density (PPFD) and growth of silver fir (Abies alba Mill.) seedlings in a forest stand dominated by spruce in the Sudety Mts. (SW Poland). Pol J Ecol 53:177-184

Haase P (1995) Spatial pattern analysis in ecology based on Ripley's K-function: introduction and methods of edge correction. J Veg Sci 6:575-582

Holmes RL (1994) Dendrochronology program library user's manual. University of Arizona, Laboratory of Tree Ring Research, Tucson, AZ, USA

Iszkuło G (2010) Success and failure of endangered tree species: low temperatures and low light availability affect survival and growth of European yew (Taxus baccata L.) seedlings. Pol J Ecol $58: 259-271$

Iszkuło G, Boratyński A (2005) Different age and spatial structure of two spontaneous subpopulations of Taxus baccata as a result of various intensity of colonization process. Flora 200:195-206

Iszkuło G, Boratyński A (2006) Analysis of the relationship between photosynthetic photon flux density and natural Taxus baccata seedlings occurrence. Acta Oecol 29:78-84

Iszkuło G, Boratyński A, Didukh Y, Romaschenko K, Pryazhko N (2005) Changes of population structure of Taxus baccata during 25 years in protected area (the Carpathian Mountains, East Ukraine). Pol J Ecol 53:13-23

Iszkuło G, Jasińska AK, Giertych MJ, Boratyński A (2009) Do secondary sexual dimorphism and female intolerance to drought influence the sex ratio and extinction risk of Taxus baccata? Plant Ecol 200:229-240

Iszkuło G, Jasińska AK, Sobierajska K (2011) Dendroecological differences between Taxus baccata males and females in comparison with monoecious Abies alba. Dendrobiology 65:55-61

Klopcic M, Boncina A (2011) Stand dynamics of silver fir (Abies alba Mill.)-European beech (Fagus sylvatica L.) forests during the past century: a decline of silver fir? Forestry 84:259-271

Kozakova R, Samonil P, Kunes P, Novak J, Kocar P, Kocarova R (2011) Contrasting local and regional Holocene histories of Abies alba in the Czech Republic in relation to human impact: evidence from forestry, pollen and anthracological data. Holocene 21:431-444

Krupiński KM, Noryśkiewicz AM, Nalepka D (2004) Taxus baccata L.-yew. In: Ralska-Jasiewiczowa M (ed) Late glacial and holocene history of vegetation in Poland based on is isopollen maps. W. Szafer Institute of Botany, Polish Academy of Sciences, Kraków, pp 209-215

Leemans R (1991) Canopy gaps and establishment patterns of spruce in two old-growth coniferous forests in central Sweden. Vegetatio 93:157-165

Lu C, Zhu Q, Denge Q (2008) Effect of frugivorous birds on the establishment of a naturally regenerating population of Chinese yew in ex situ conservation. Integr Zool 3:186-193

Lyubenova M, Nedelchev R (2001) Influence of human factors on population of Taxus baccata L. J Balkan Ecol 4:382-388

Pelliser F, Souto XC (1999) Allelopathy in northern temperate and boreal semi-natural woodland. Crit Rev Plant Sci 18:637-652

Perrin PM, Kelly DL, Mitchell FJG (2006) Long-term deer exclusion in yew-wood and oakwood habitats in southwest Ireland: natural regeneration and stand dynamics. For Ecol Manag 236:356-367

Piovesan G, Saba EP, Biondi F, Alessandrini A, Di Filippo A, Schirone B (2009) Population ecology of yew (Taxus baccata L.) in the Central Apennines: spatial patterns and their relevance for conservation strategies. Plant Ecol 205:23-46

Salas Ch, LeMay V, Nunez P, Pacheco P, Espinosa A (2006) Spatial patterns in an old-growth Nothofagus oblique forest in southcentral Chile. For Ecol Manag 231:38-46 
Sanz R, Pulido F, Nogués-Bravo D (2009) Predicting mechanisms across scales: amplified effects of abiotic constraints on the recruitment of yew Taxus baccata. Ecography 32:993-1000

Scheeder T (1994) Die Eibe (Taxus baccata L.): Hoffnung flit ein fast verschwundenes Waldvolk. IHW-Verlag, Eching

Schirone B, Ferreira RC, Vessella F, Schirone A, Piredda R, Simeone MC (2010) Taxus baccata in the Azores: a relict form at risk of imminent extinction. Biodivers Conserv 19:1547-1565

Suszka B (1983) Rozmnażanie generatywne. In: Białobok S (ed) Jodła pospolita Abies alba Mill. PWN, Warszawa-Poznań, pp 175-265

Szwagrzyk J, Szewczyk J, Bodziarczyk J (2001) Dynamics of seedling banks in beech forest: results of a 10-year study on germinantion, growth and survival. For Ecol Manag 141:237-250
Szymura TH, Dunajski A, Aman I, Makowski M, Szymura M (2007) The spatial pattern and microsites requirements of Abies alba natural regeneration in the Karkonosze Mountains. Dendrobiology 58:51-57

Thomas PA, Polwart A (2003) Taxus baccata L. Biological flora of the British isles 229. J Ecol 91:489-524

Thomas AL, Gegout JC, Landmann G, Dambrine E, King D (2002) Relation between ecological conditions and fir decline in a sandstone region of the Vosges mountains (northeastern France). Ann For Sci 59:265-273

Vieilledent G, Courbaud B, Kunstler G, Dhote JF (2010) Mortality of silver fir and Norway Spruce in the Western Alps - a semiparametric approach combining size-dependent and growthdependent mortality. Ann For Sci 67:305 